\title{
PROGNOSTIC VALUE OF CLINICAL AND NEUROIMAGING RISK FACTORS OF MULTIPLE SCLEROSIS ACTIVITY
}

ковys TAtianA A., C. Med. Sci., Head of Kyiv City Center of Multiple Sclerosis, Kyiv City Clinical Hospital № 4, doctoral candidate of the Department of neurology of O.O. Bogomolets National Medical University, Ukraine, Kyiv, tel. +38-067-287-31-65, e-mail: tkobys@ukr.net

\begin{abstract}
Purpose of the study. To improve predictive assessment of multiple sclerosis (MS) activity on the basis of complex clinical-neurological and neuroimaging prospective study. Research methods. A prospective ten-year study of 180 patients with MS starting with the first clinical signs. MRI examination was performed on a GE unit Signa Excite HD $1,5 \mathrm{~T}$, determined by the number of $\mathrm{T} 2$ lesions including lesiona $>3 \mathrm{~mm}$, and $\mathrm{T} 1 \mathrm{Gd}+$ lesions. Results and discussion. We proved the effect of frequency of relapses in the beginning of the disease and the type of FS affected by CIS on the long-term prognosis of clinical activity. Based on the MRI monitoring we identified prognostic risk factors for the activity of the disease in different periods of the study — namely, the number of T2 lesions, their size and location. Conclusion. Prediction of the course of MS activity should be carried out taking into account the clinical and neuroimaging evidence of disease activity in different periods from its onset.
\end{abstract}

Key words: multiple sclerosis, clinical disease activity, lesions, disability progression.

For reference: Kobys TA. Prognostic value of clinical and neuroimaging risk factors of multiple sclerosis activity. The Bulletin of Contemporary Clinical Medicine. 2016; 9 (3): 12-18.

\section{ПРОГНОСТИЧЕСКОЕ ЗНАЧЕНИЕ КЛИНИКО- НЕЙРОВИЗУАЛИЗАЦИОННЫХ ФАКТОРОВ РИСКА АКТИВНОСТИ ТЕЧЕНИЯ РАССЕЯННОГО СКЛЕРОЗА}

\begin{abstract}
КОБЫСЬ ТАТЬЯНА АЛЕКСАНДРОВНА, канд. меД. Наук, руководитеЛЬ Киевского городского центра рассеянного склероза, Киевская городская клиническая больница № 4, соискатель кафедры неврологии Национального медицинского университета им. А.А. Богомольца, Украина, Киев, тел. +38-067-287-31-65, e-mail: tkobys@ukr.net
\end{abstract}

\begin{abstract}
Реферат. Цель исследования - повысить уровень прогностической оценки активности течения рассеянного склероза на основе комплексного клинико-неврологического и нейровизуализационного проспективного исследования. Материал и методы. Проведено проспективное 10-летнее исследование 180 больных рассеянным склерозом, начиная с первых клинических признаков. Магнитно-резонансное томографрическое обследование проводилось на аппарате GE, Signa Excite HD 1,5T, определялось количество Т2-очагов, в том числе размером более 3 мм, T1 и Gd+очагов. Результаты и их обсуждение. Доказано влияние частоты рецидивов в начале заболевания и виды поражения функциональной системы при клинически изолированном синдроме на долгосрочный прогноз клинической активности. На основании МРТ-мониторинга определены прогностические факторы риска активности течения заболевания в разные периоды исследования, а именно: количество Т2очагов, их размеры и локализация. Заключение. Прогнозирование активности течения рассеянного склероза должно проводиться с учетом клинических и нейровизуализационных признаков активности заболевания в разные периоды от его начала.
\end{abstract}

Ключевые слова: рассеянный склероз, клиническая активность заболевания, очаги, прогрессирование инвалидизации.

Для ссылки: Kobys, Т.A. Prognostic value of clinical and neuroimaging risk factors of multiple sclerosis activity / T.A. Kobys // Вестник современной клинической медицины. - 2016. - Т. 9, вып. 3. - С.12-18.

ntroduction. The problem of early diagnosis and

prognosis of multiple sclerosis (MS), especially in the initial stages, remains extremely topical in the world to date $[1,14,15]$. Currently there are more than 3 million MS patients in the world, and further increase in its prevalence is observed. Forecast of the disease activity of multiple sclerosis (MS) after the first clinical disease attack, called clinically isolated syndrome (CIS), and in the first years after the onset of the disease is very important for neurologists and patients, due to the need to make a decision on starting pathogenetic treatment in order to preserve the ability to work.

Review of studies on the topic. Different rates of disease progression and time periods until significant disability generate interest in determining various aspects and features of the clinical activity of demyelinating process in MS, which is clinically determined by the frequency of exacerbations and progression of disability $[2,7,9,11,12]$. A. Degenhardt et al. pointed out that the negative prognostic factors of high disease activity is high recurrence rate and reaching significant disability in the first five years of the disease, lesions of more functional systems (FS), short interval between the first and second relapse [5].

In a 20,6-year retrospective study of 2,477 patients with MS in the UK and Canada the impact of relapses at different stages of disease on its progression was determined and proved to be ambiguous [12]. Results of 
a two-decade follow-up of 169 patients with benign MS were pusblished, in which for 10 years after the debut of the disease EDSS score was less than 3 points. [10] Preservation for a long period of time (10 years from MS onset) of the disability level of less than 3 points as measured by EDSS, the so-called benign benign MS, in only a small proportion of patients, led to further detailed examination of all the factors that influence the disease progression [4].

At the same time magnetic resonance imaging (MRI) is an integral part of the MS diagnosis and evaluation of its current activity $[3,8]$. The nature of a «clinico-radiological paradox», i.e. inconsistency of MRI picture and clinical manifestations of the disease, which is indicated by weak correlation between clinical and MRI signs of disease, has been discussed in the literature for long time. K. Lovblad et al., 2010 [8] attach great importance to the role of MRI in the diagnosis and monitoring of diseases, as well as held a generalization of achievements and unresolved problems of the neuroimaging era. At the same time, the researchers point out that in addition to the shortcomings of existing clinical and MRI studies, the presence of «silent» lesions is important, therefore it remains important to identify new predictors of disease activity.

A lengthy 20-year study by L. Fisniku et al. Queen Sguare of a large number of patients with CIS (140 patients) showed that the number of lesions on T2weighted images at the time of CIS is not only correlated with the subsequent transition to the MS, but also correlates with the risk of losing the ability to walk without support after 20 years [7]. The researchers pointed out that the findings of relatively weak correlations between the MRI picture and clinical manifestations of the disease have been made prematurely. MRI indicators are important predictors of the development of clinical manifestations of MS. The volume of brain lesions and their changes correlate with disability within 20 years of onset.

T. Ziemssenn, who analyzed scientific papers on clinical and neuroimaging relationships in MS for the past twenty years, pointed out that the results of the earlier studies on the forecast of MS development in patients with optic neuritis in terms of the number of demyelination lesions showed positive results [14].

In 2012, a new long-term study of 342 patients with RRMS that has set new challenges for the researchers was published. For the first time deterioration of dynamic MRI pattern in patients with benign MS was revealed [4]. Given the large proportion of patients who had changes, the authors concluded that the relevant reliable criteria by which patients remain with benign "soft" type of disease course is yet to be determined.

Later many other researchers described the relationship between the number of lesions on T2weighted images, the initial rate of increase in the number of lesions, the number of lesions accumulating contrast agent $[3,10,12]$ and clinical disease activity.

There is an urgent need to identify new possible predictors of progression of disability in MS, as well as a need for a comparative analysis of the data in different time periods of patient monitoring that will determine the new factors that define disease activity and help optimize the forecast.
Objective. To improve current prognostic assessment of MS activity based on a comprehensive clinicalneurological and neuroimaging prospective study.

Material and methods. A total of 180 patients (88 women and 92 men) with MS were followed up in Kyiv City Center of Multiple Sclerosis on the basis of City Hospital № 4 during 2003-2014 since the first clinical signs of the disease - clinically isolated syndrome (CIS). All patients subsequently developed RRMS. The total follow-up of patients lasted $(10,25 \pm 0,25)$ years. The entire follow-up term was divided into several periods during which we analyzed the results of clinical and instrumental examination.

Period I - beginning of the study, CIS (2003-2004). Period IA - 2005-2006.

Period II - 2008-2009. Period III - 2009-2010.

Period IV - 2010-2011. Period V - 2011-2012.

Period VI - end of the prospective study (20132014).

Severity of neurological symptoms was evaluated using EDSS (Kurtzke J., 1983). We also determined the frequency of clinical relapses.

M.R. Brain images were obtained by MRI scanner GE Signa Excite HD 1,5T in the "Boris» medical clinic according to a standard protocol using the pulse sequences fast spin echo (FSE), spin echo (SE), T2FLAIR, as well as Dual Echo for images weighed in T2 and T1 proton density. We estimated the number of hyperintense lesions on T2-weighted images, including a number of lesions of more than $3 \mathrm{~mm}$, the number of T1-foci and Gd + lesions.

Statistical processing of the data was performed using the Statistisa 10,0 software package («StatSoft, Inc», USA) and Microsoft $®$ Excel 2010 («Microsoft Corporation», USA). Diagrams were built using Microsoft Graph Editor (C) Microsoft Corporation, 2010). To analyze the time period up to the development (formation) of certain clinical conditions (relapses, disability progression, etc.) in patients from the clinical study groups we used the Kaplan-Meier method. Analyzing the impact of factor variables and individual levels of clinical, neuroimaging and immunological parameters as predictors of progression of disability, we determined their prognostic characteristics using odds ratio (OR) with 95\% confidence intervals and statistical significance of the results OR $(95 \%$ $\mathrm{Cl})$.

Research results and discussion. During a tenyear prospective study we determined clinical and neuroimaging manifestations of demyelinating process activity in MS, to which end, for each period of the study, we recorded relapse frequency, level of disability as measured by the EDSS and the number of MRI lesions (T2, including larger than $3 \mathrm{~mm}$, and $\mathrm{T} 1 \mathrm{Gd}+$ ) followed by an analysis of the relationships between these traits.

We started by analyzing the relapse frequency and level of disability as measured by the EDSS for each period and evaluated the correlation relationship with the type of FS affected by CIS (Table 1).

When the disease started with stem disorders, in both periods we found statistically significant direct correlation with average relapse frequency $(r=0,521$; $p<0,01, r=0,556 ; p<0,01)$ and with EDSS score 
Table 1

Level of correlation between the type of CIS and clinical signs of disease activity after 3 and 6 years since MS onset

\begin{tabular}{|c|l|c|c|c|c|}
\hline № & $\begin{array}{c}\text { FS affected } \\
\text { by CIS }\end{array}$ & $\begin{array}{c}\text { Relapse frequency } \\
\text { after 3 years (period IA) }\end{array}$ & $\begin{array}{c}\text { EDSS score } \\
\text { after 3 years (period IA) }\end{array}$ & $\begin{array}{c}\text { Relapse frequency } \\
\text { after 6 years (period II) }\end{array}$ & $\begin{array}{c}\text { EDSS score after 6 years } \\
\text { (period II) }\end{array}$ \\
\hline 1 & Visual & $0,378^{*}$ & 0,189 & 0,216 & $0,234^{*}$ \\
\hline 2 & Stem & $0,521^{* *}$ & $0,223^{*}$ & $0,556^{* *}$ & $0,348^{*}$ \\
\hline 3 & Pyramidal & $0,551^{* *}$ & 0,178 & 0,166 & $0,567^{* *}$ \\
\hline 4 & Cerebellar & 0,054 & 0,189 & $0,323^{*}$ & $0,230^{*}$ \\
\hline 5 & Sensory & $0,276^{*}$ & 0,175 & $0,342^{*}$ & 0,189 \\
\hline 6 & Cognitive & 0,066 & 0,168 & 0,75 & 0,179 \\
\hline
\end{tabular}

$(r=0,223 ; p<0,05, r=0,348 ; p<0,05)$, i.e. affection of this FS has prognostic significance for increased clinical activity of the MS in the first six years of onset. When the disease started with pyramidal disorders, average direct correlation was detected with relapse frequency in three years after MS onset $(r=0,551 ; p<0,01)$, and with EDSS score in six years $(r=0,567 ; p<0,01)$. The results indicated that the clinical disease activity over three years manifested in relapses, and over six years in growing degree of disability as measured by EDSS. Onset of the disease with sensory disorders showed weak but statistically significant correlation with relapse frequency, both three and six years after the onset of illness $(r=0,276 ; p<0,05, r=0,346 ; p<0,05)$ and no correlation with EDSS score, therefore the disease starting with disorder of this FS predicts more favorable disease course and minimal disability progression. Smaller values and patterns were observed in the cases of disease onset with visual and cerebellar disorders, and lacked in the case of cognitive disorders. At a later stage, type of CIS-affected FS tended to have weaker correlations with relapse frequency and increased correlation with level of disability as measured by EDSS.

The rate of disability progression is one of the important indicators of clinical disease course. To assess the risk of disability progression used we used the odds ratio method. We analyzed the impact of relapse frequency recorded in the beginning of the disease on the rate of reaching the EDSS score of $>3,0$ points in each study period.
As seen from Fig. 1, only after 9-10 years of disease onset ( $\mathrm{V}-\mathrm{VI}$ period) we recorded significantly higher odds of achievement of EDSS $>3,0$ (moderate disability), depending on relapse frequency in the initial stage of the disease: [OR $(95 \% \mathrm{Cl})=3,11(1,16-8,32)$; $p=0,021]$ and [OR $(95 \% \mathrm{Cl})=3,68(1,28-10,61) ; p=0,01]$ respectively.

Results of statistical analysis showed that high relapse frequency ( 2 or more per year) recorded in the first years of the disease did not affect the risk of reaching EDSS score $>3,0$ points in the same period of observation and the next two years. The risk of reaching disability of $>3,0$ points significantly increased only after 9-10 years of disease onset (V-VI periods). It proves the prognostic value of relapse frequency in the first years of the disease with increased odds ratio of disability progression in the long term.

Monitoring of the demyelinating process on MRI, beginning with $\mathrm{CIS}$, for each study period showed both the presence and absence of correlations with clinical signs of the disease. The most signification results were as follows.

We determined the timing of the third relapse in MS patients. We used this indicator for the analysis, because we believed that the term of early relapses in MS may have a predictive value for the further activity of MS. Using the Kaplan-Meier method, we found that the rate of occurrence of the third relapse is statistically significantly affected by the presence of 9 or more T2 lesions $(p=0,004)$ (Fig. 2).

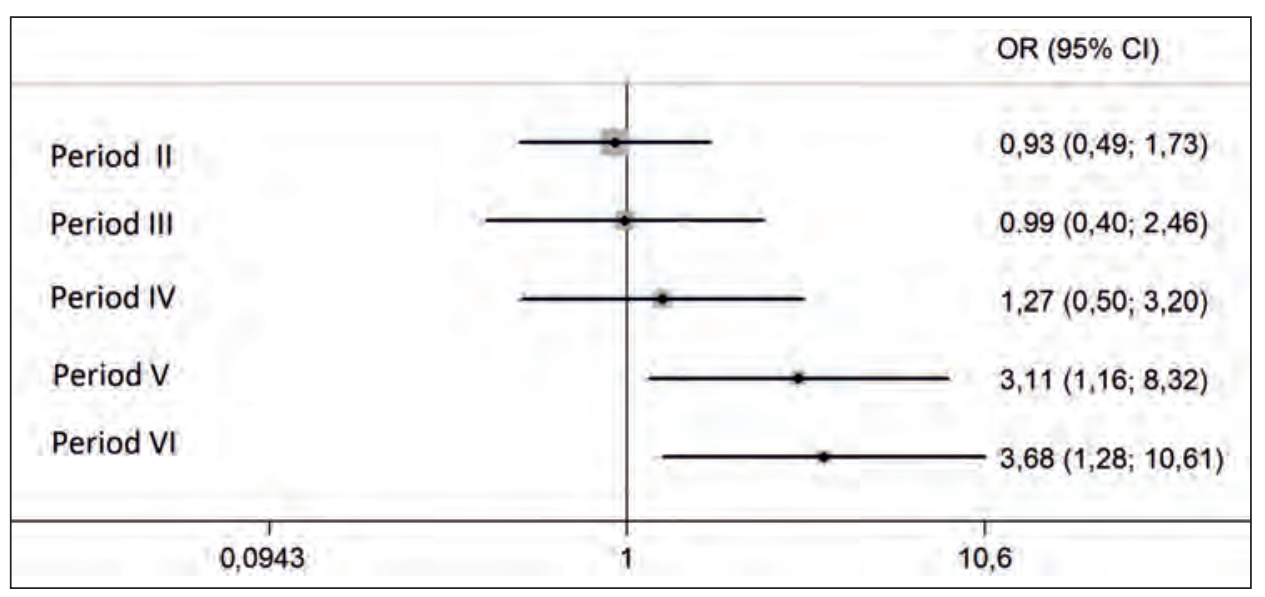

Fig. 1. Risk of MS patients reaching EDSS score $>3,0$ points depending on relapse frequency in the first six years of the disease 


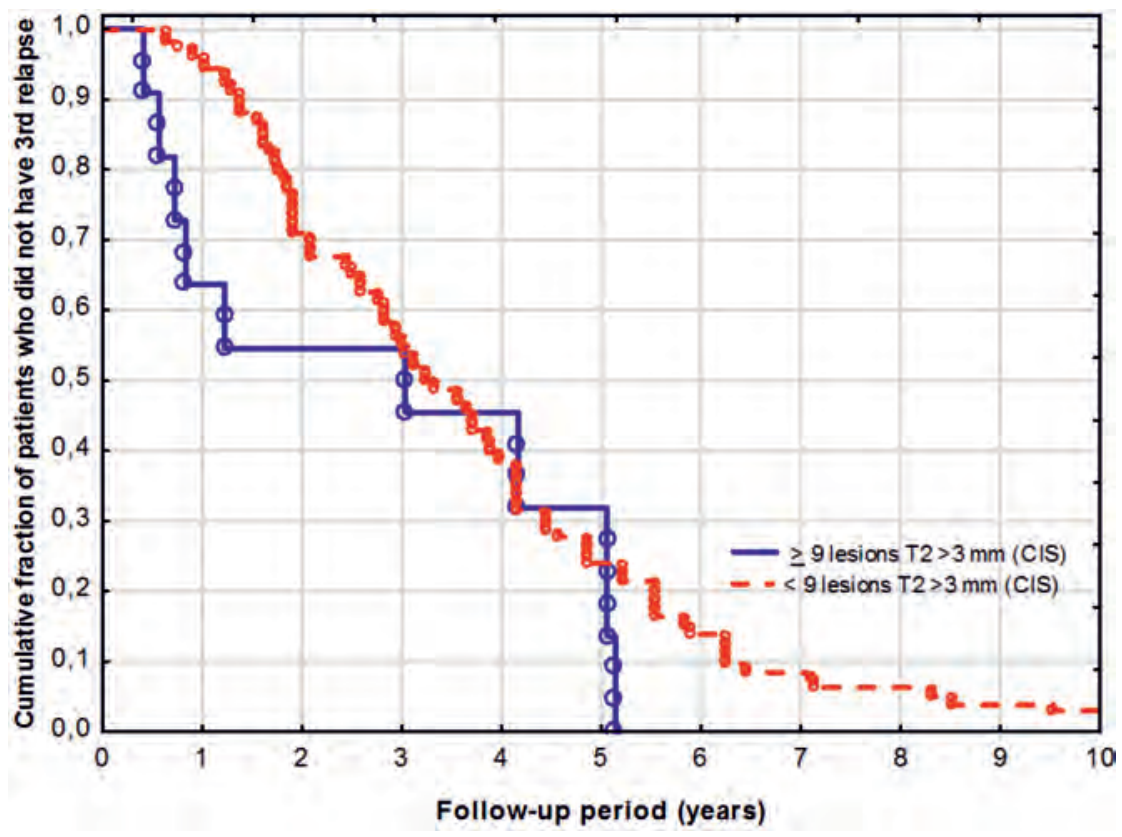

Fig. 2. Analysis of the time periods before the third relapse in patients with RRMS depending on the number of T2 lesions $>3 \mathrm{~mm}$ under CIS

During the ten-year follow-up, all patients who had at least 9 T2 lesions with the size $>3 \mathrm{~mm}$ under $\mathrm{CIS}$ had the third relapse, and if there are 9 or more T2 lesions with the $>3 \mathrm{~mm}$ at the first clinical sign of the third relapse developed during the first five years of the disease $(p=0,0048)$.

In MS patients having three or more Gd + lesions, the risk of relapse grew more than 2-fold $(F=1,99$; $p=0,0002)$, while in CIS patients we did not observe any significant effect for the $\mathrm{Gd}+$ lesions on the rate of occurrence of the third relapse. Also, there was no risk of relapse depending on the number T1 lesions in patients with MS and CIS. The total number of T2 lesions in patients with MS had a mixed impact on the occurrence of relapse. We discovered a statistically significant trend indicating that the presence of more cells meant that the third relapse is likely to occur later $(\mathrm{F}=1,2 ; p=0,126)$. We evaluated the effect of this indicator in patients with more active clinical course, who had the 6 th relapse. It was found that in patients with MS in the presence of more than 20 T2 lesions the increased rate of occurrence of the 6th relapse was statistically significant $(F=1,57 ; p=0,0035)$. The results could indicate that, when new $\mathrm{T} 2$ lesions are formed, clinical manifestations of the disease may be registered in the future attacks of the disease.

It was also proven that in cases where under CIS we observed periventricular and subtentorial localization of lesions, the risk of reaching a moderate level of disability on EDSS scale $>3,0$ points significantly increased: OR $(95 \% \mathrm{Cl})=2,25(1,0-4,9) ; p=0,031$ and $\mathrm{OR}(95 \% \mathrm{Cl})=1,9$ $(1,1-3,5) ; p=0,022$. Where lesions were localized in the corpus callosum, we did not observe any risk of reaching EDSS of 3,0 points (Table 2).

Therefore, the above localizations of cells under CIS are the most prognostically unfavorable for reaching a moderate level of disability as measured by EDSS in patients with RRMS in the short term (Fig. 3).

The progression rate of disability in MS patients depending on the number of T2 lesions (more than 20

Table 2

Risk of reaching EDSS $>3,0$ points in patients with CIS (I period), depending on the localization of lesions

\begin{tabular}{|c|c|c|c|c|}
\hline Localization & $\begin{array}{l}\text { Groups of patients } \\
(n)\end{array}$ & $\begin{array}{l}\text { Incidence of reaching } \\
\text { EDSS }>3 \text { points, } n(\%)\end{array}$ & $\begin{array}{l}\text { Odds ratio } \\
\text { OR }(95 \% \mathrm{Cl})\end{array}$ & $p$ \\
\hline \multirow[t]{2}{*}{ Juxtracortical } & Yes (139) & $63(45,3)$ & \multirow{2}{*}{$\begin{array}{c}2,0 \\
(0,9-4,4)\end{array}$} & \multirow[t]{2}{*}{0,054} \\
\hline & No (41) & $17(24,3)$ & & \\
\hline \multirow[t]{2}{*}{ Periventricular } & Yes (140) & $60(42,9)$ & \multirow{2}{*}{$\begin{array}{c}2,25 \\
(1,0-4,9)\end{array}$} & \multirow{2}{*}{0,031} \\
\hline & No $(40)$ & $10(25,0)$ & & \\
\hline \multirow[t]{2}{*}{ Infratentorial } & Yes (79) & $40(51,3)$ & \multirow{2}{*}{$\begin{array}{c}1,9 \\
(1,1-3,5)\end{array}$} & \multirow[t]{2}{*}{0,022} \\
\hline & No (101) & $36(35,6)$ & & \\
\hline \multirow[t]{2}{*}{ Corpus callossum } & Yes (91) & $36(39,6)$ & \multirow{2}{*}{$\begin{array}{c}0,36 \\
(0,18-0,69\end{array}$} & \multirow[t]{2}{*}{0,0018} \\
\hline & No $(60)$ & $39(65,0)$ & & \\
\hline \multirow[t]{2}{*}{ Spinal cord } & Yes (25) & $7(28,0)$ & \multirow{2}{*}{$\begin{array}{c}0,50 \\
(0,20-1,26)\end{array}$} & \multirow[t]{2}{*}{0,108} \\
\hline & No (155) & $68(43,9)$ & & \\
\hline
\end{tabular}




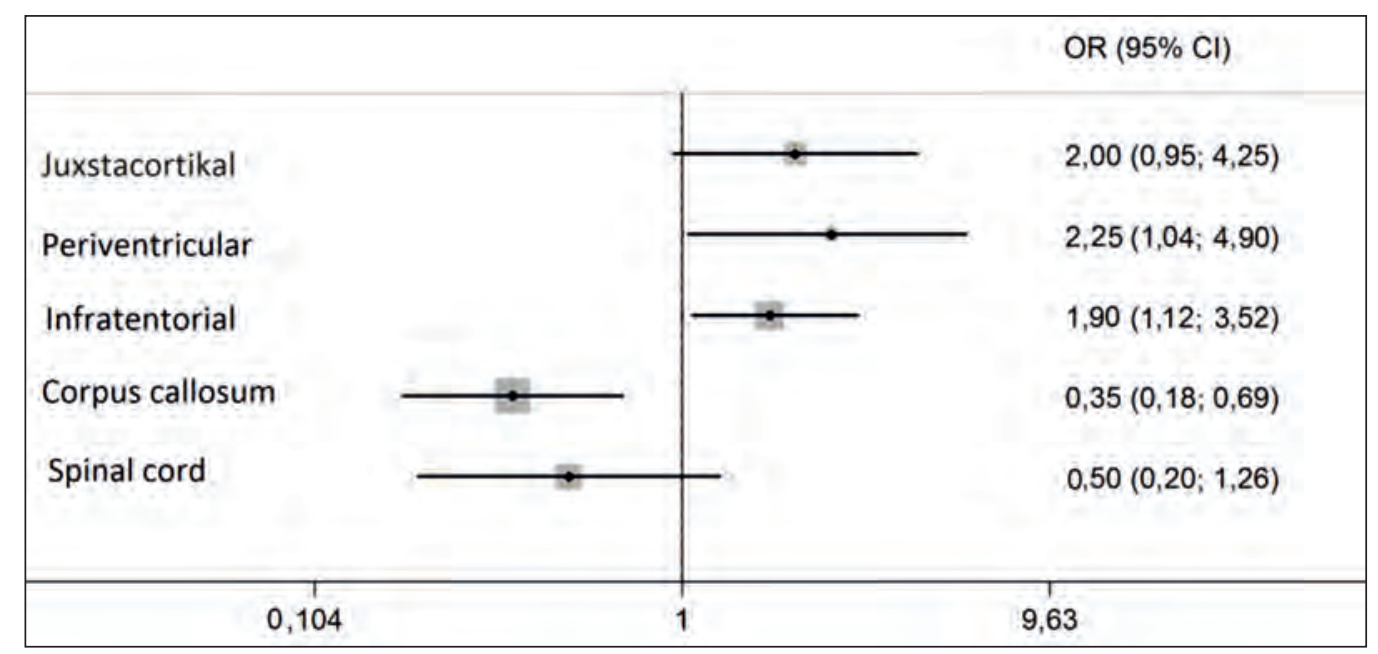

Fig. 3. Risk of reaching EDSS $>3,0$ points in RRMS patients depending on lesion localization under CIS (I period)

and less than 20) estimated using the Kaplan-Meier method statistically confirmed disease duration value in achieving moderate disability as measured by EDSS. Thus, after seven years of onset (IV period), reduction of the proportion of patients with EDSS $<3$ points grew almost 2-fold $(\mathrm{F}=5,3 ; p=0,006)$. That is, in the IV study period, when the number of T2 lesions was $\geq 20$ and $<20$ it was $32,7 \%$ and $58,9 \%$, respectively, in the $\mathrm{V}$ period it was $12,7 \%$ and $40,7 \%$, in the $\mathrm{VI}$ period it was $2,5 \%$ to $24,5 \%$ (Fig. 4).

While analyzing the impact of the MRI picture existing at the time of period II on the rate of disability progression we found a high odds ratio of reaching EDSS $>3,0$ points in six years after the onset of the disease when $\geq 9 \mathrm{~T} 2$ lesions $>3 \mathrm{~mm}$ were registered: OR $(95 \%$ Cl $)=21,46(9,58-48,09)$ (Fig. 5).
This figure can be considered one of the most important indicators of reaching EDSS $>3,0$ points. Also, if in the second period we observed 20 or more T2 lesions, there was a high odds ratio of reaching EDSS $>3,0$ points: OR $(95 \% \mathrm{Cl})=3,62(1,88-6,96)$.

Conclusion. As a result of the ten-year prospective clinical and neuroimaging study of patients with MS we firther improved one of the most important issues of neurology - to clarify and define new possible risk factors of MS activity. The results are of practical importance in view of the fact that the identification of predictors of disease activity allows making a decision on the timely assignment of pathogenetic therapy of both the first and second lines.

Based on the results of the study we made the following findings:

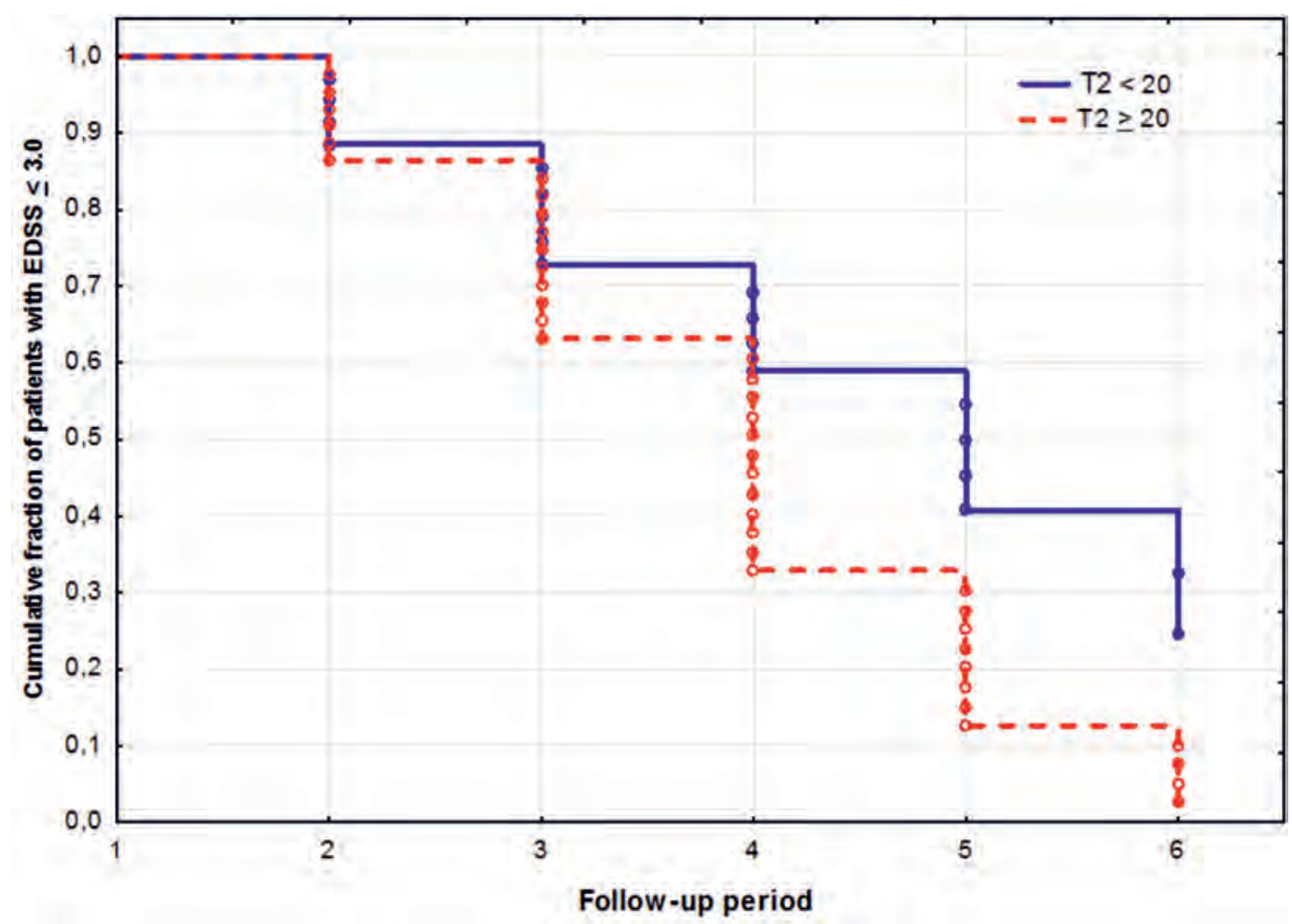

Fig. 4. Analysis of the time intervals before reaching EDSS $>3,0$ points depending on the total number of T2 lesions in each study period 


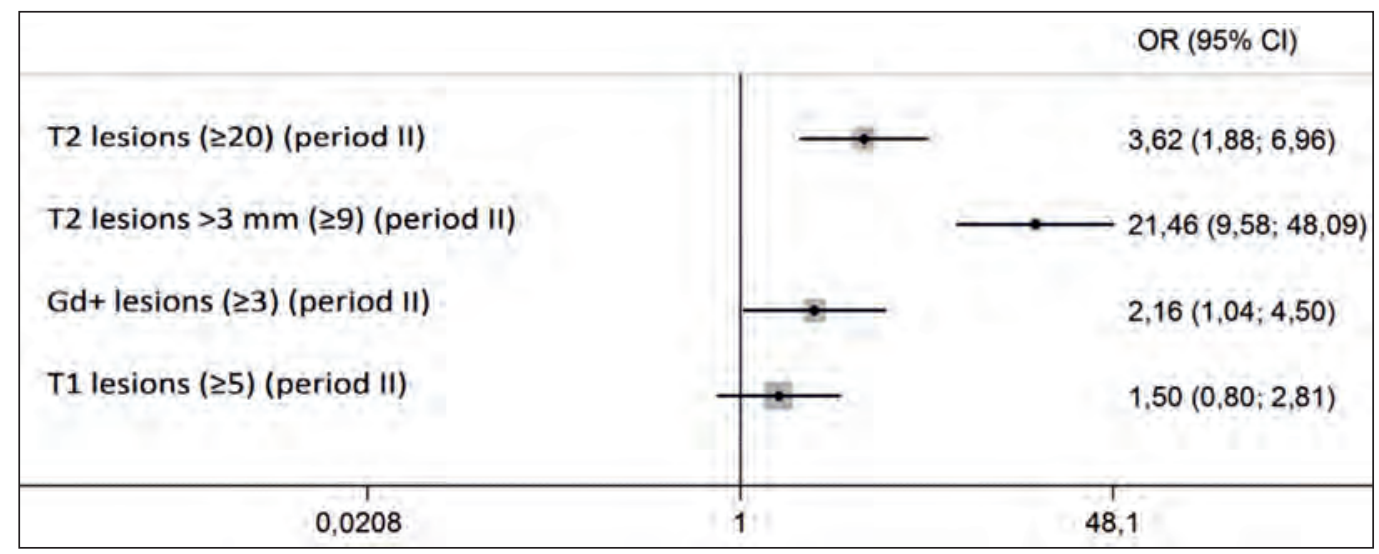

Fig. 5. Risk of reaching EDSS $>3,0$ points in patients with RRMS (period II) depending on MRI parameters

1. Prediction of the course of MS activity should be carried out taking into account the clinical and neuroimaging evidence of disease activity in different periods from its onset.

2. Type of the CIS-affected FS is important for predicting the clinical disease activity. Onset of the disease with stem and pyramidal FS has the most unfavorable prognosis.

3. High relapse frequency during the early years of the disease is a significant prognostic factor for MS patients reaching a moderate degree of disability as assessed by EDSS in the long term - 9-10 years from its onset.

4. The risk of MS relapse increases with registration of 9 or more T2 lesions during CIS. The increase in the total number of lesions of $\mathrm{T} 2$ to 20 and more in the early stages of the disease may not find clinical output, that is, the appearance of new T2 lesions the clinical manifestations of the disease may not be recorded at the time of the next attack.

5. The main neuroimaging predictors of disability progression in MS are the presence of 9 or more T2 lesions with larger than $3 \mathrm{~mm}$, infratentorial and periventricular localization of lesions during $\mathrm{CIS}$, total number of T2 lesions. Moreover, significant odds of the presence of 20 or more T2 lesions of T2 occur with increasing duration of the disease for more than seven years.

Transparency of the study. The study did not have sponsorship. The author is solely responsible for the provision of the final version of the manuscript for publication.

Declaration of financial and other relationships. The author was personally involved in developing the concept and design of the study and in the writing of the manuscript. The final version of the manuscript has been approved by the author. The author did not receive a fee for the study.

\section{ЛИТЕРАТУРА}

1. Шмидт, Т.Е. Рассеянный склероз / Т.Е. Шмидт, Н.Н. Яхно. - М.: МЕДпресс-информ, 2012. - 272 с.

2. Ann, Yeh E. Multiple sclerosis: predicting risk and delaying progression / Yeh E. Ann, B. Weinstock Guttman // Neurology. - 2010. — Vol. 9, № 1. - P.7-9.
3. Magnetic resonance imaging metrics and their correlation with clinical outcomes in multiple sclerosis: a review of the literature and future perspectives / D. Bar-Zohar, F. Agosta, D. Goldstaub, M. Filippi // Mult. Scler. - 2008. — Vol. 14, № 6. - P.719-727.

4. Correale, J. Benign multiple sclerosis: a new definition of this entity is needed / J. Correale, I. Peirano, L. Romano // Mult. Scler. - 2012. - Vol. 18, № 2. - P.210218.

5. Clinical prognostic factors in multiple sclerosis: a natural history review / A. Degenhardt, S.V. Ramagopalan, A. Scalfari, G.C. Ebers // Nat. Rev. Neurol. - 2009. Vol. 5, № 12. - P.672-682.

6. Disability and T2 MRI lesions: a 20-year follow-up of patients with relapse onset of multiple sclerosis / L.K. Fisniku, P.A. Brex, D.R. Altmann [et al.] // Brain. 2008. - Vol. 131 (Pt. 3). - P.808-817.

7. Disability in multiple sclerosis: A reference for patients and clinicians / I. Kister, E. Chamot, A.R. Salter [et al.] // Neurology. - 2013, Mar. 12. - Vol. 80, № 11. P.1018-1824.

8. MR imaging in Multiple Sclerosis: review and recommendation for current practice / K.O. Lovblad, N. Anzalone, A. Doflier [et al.] // AJNR (Am. J. Neuroradiol). - 2010. - Vol. 31. - P.983-989.

9. Characterising aggressive multiple sclerosis / S. Menon, A. Shirani, H. Zhao [et al.] // J. Neurol. Neurosurg. Psychiatry. — 2013. — Vol. 84, № 11. - P.1192-1198.

10. Sayao, A.L. Longitudinal follow-up of 'benign' multiple sclerosis at 20 years / A.L. Sayao, V. Devonshire, H. Tremlett // Neurology. - 2007. — Vol. 68, № 7. P.496-500.

11. Early relapses, onset of progression, and late outcome in multiple sclerosis / A. Scalfari, A. Neuhaus, M. Daumer [et al.] // JAMA Neurol. - 2013. - Vol. 70, № 2. P.214-222.

12. The natural history of multiple sclerosis, a geographically based study. Relapses and long-term disability / A. Scalfari, A. Neuhaus, A. Degenhardt [et al.] // Brain. - 2010. Vol. 133 (Pt. 7). - P.1914-1929.

13. UBC Neurologists. Impact of multiple sclerosis relapses on progression diminishes with time $/ \mathrm{H}$. Tremlett, M. Yousefi, V. Devonshire [et al.] // Neurology. - 2009. - Vol. 73, № 20. - P.1616-1623.

14. New perspectives in the natural history of multiple sclerosis / H. Tremlett, Y. Zhao, P. Rieckmann, M. Hutchinson // Neurology. — 2010. — Vol. 74, № 24. - P.2004-2015.

15. Ziemsenn, T. New Era in Multiple Sclerosis: New Consideration for Therapeutic Approaches // T. Ziemsenn, M. Tintore. - Elsevier, 2010. - 94 p. 


\section{REFERENCES}

1. Shmidt TE, Jahno NN. Rassejannyj skleroz [Multiple Sclerosis]. Moscow: MEDpress-inform. 2012; 272 p.

2. Ann Yeh E, Guttman Bianca Weinstock. Multiple sclerosis: predicting risk and delaying progression. Neurology. 2010; 9 (1): $7-9$.

3. Bar-Zohar D, Agosta F, Goldstaub D, Filippi M. Magnetic resonance imaging metrics and their correlation with clinical outcomes in multiple sclerosis: a review of the literature and future perspectives. Mult Scler. 2008; 14 (6): 719-727.

4. Correale J, Peirano I, Romano L. Benign multiple sclerosis: a new definition of this entity is needed. Mult Scler. 2012; 18 (2): $210-218$.

5. Degenhardt A, Ramagopalan SV, Scalfari A, Ebers GC. Clinical prognostic factors in multiple sclerosis: a natural history review. Nat Rev Neurol. 2009; 5 (12): 672-682.

6. Fisniku LK, Brex PA, Altmann DR et al. Disability and T2 MRI lesions: a 20-year follow-up of patients with relapse onset of multiple sclerosis. Brain. 2008; 131 (Pt 3): 808-817.

7. Kister I, Chamot E, Salter AR, Cutter GR, Bacon TE, Herbert J. Disability in multiple sclerosis: A reference for patients and clinicians. Neurology. 2013; 80 (11): 10181824.
8. Lovblad KO, Anzalone N, Doflier A et al. MR imaging in Multiple Sclerosis: review and recommendation for current practice. AJNR (Am J Neuroradiol). 2010; 31: 983-989.

9. Menon S, Shirani A, Zhao H et al. Characterising aggressive multiple sclerosis. J Neurol Neurosurg Psychiatry. 2013; 84 (11): 1192—1198.

10. Sayao AL, Devonshire V, Tremlett H. Longitudinal followup of 'benign' multiple sclerosis at 20 years. Neurology. 2007; 68 (7): 496-500.

11. Scalfari A, Neuhaus A, Daumer M, Deluca G, Muraro P, Ebers $G$. Early relapses, onset of progression, and late outcome in multiple sclerosis. JAMA Neurol. 2013; 70 (2): $214-222$.

12. Scalfari A, Neuhaus A, Degenhardt A et al. The natural history of multiple sclerosis, a geographically based study. Relapses and long-term disability. Brain; 2010; 133 (Pt 7): 1914-1929.

13. Tremlett H, Yousefi M, Devonshire V, Rieckmann P, Zhao Y. UBC Neurologists; Impact of multiple sclerosis relapses on progression diminishes with time. Neurology; 2009; 73 (20): 1616-1623.

14. Tremlett $\mathrm{H}$, Zhao $\mathrm{Y}$, Rieckmann $\mathrm{P}$, Hutchinson M. New perspectives in the natural history of multiple sclerosis. Neurology. 2010; 74 (24): 2004-2015.

15. Ziemsenn T, Tintore M. A New Era in Multiple Sclerosis: New Consideration for Therapeutic Approaches. Elsevier. 2010; 94 p.

\section{КАК ВЫПОЛНЯЮТСЯ ПОЛОЖЕНИЯ GOLD 2014 В РЕАЛЬНОЙ ВРАЧЕБНОЙ ПРАКТИКЕ?}

КУПАЕВ ВИТАЛИЙ ИВАНОВИЧ, докт. мед. наук, профессор, зав. кафедрой семейной медицины ИПО ГБОУ ВПО «Самарский государственный медицинский университет» Минздрава Росси, Россия, 443099, Самара, ул. Чапаевская, 89, тел.+7-927-256-09-27, e-mail: vk1964sam@rambler.ru

ЩЕЛКУНОВА ЛАРИСА АНАТОЛЬЕВНА, врач-ПУЛЬМОНОЛОГ ГБУЗ СО «ГОродСКая ПОЛИкЛИника № 15», Россия, Самара, ул. Фадеева, 56a, e-mail: larisonn@rambler.ru НАГОВСКАЯ НАТАЛЬЯ ГЕННАДЬЕВНА, ЗаВ. ПОЛИКЛИНИчеСКИМ ОТДеЛеНИем ГБУЗ СО «ГородСКая поликлиника № 4», Россия, 443051, Самара, ул. Свободы, 185, e-mail: natalya.nagovskaya@mail.ru ГУСАРОВ КОНСТАНТИН ВАЛЕРЬЕВИЧ, асПираНТ КафедрЫ СемеЙНОЙ МедИцинЫ ИПО ГБОУ ВПО «СамарСКИЙ государственный медицинский университет» Минздрава России, Россия, 443099, Самара, ул. Чапаевская, 89, e-mail:dok_gus@mail.ru

Реферат. Цель исследования - оценка возможности реализации новых положений GOLD 2014 во врачебной практике амбулаторно-поликлинического звена РФ. Материал и методы. Проведен анализ электронного регистра 599 больных хронической обструктивной болезнью легких одной из поликлиник г. Самары и оценена возможность ведения 76 пациентов в реальной врачебной практике по критериям GOLD 2014. Проанализирована терапия 76 больных через 8 нед амбулаторного наблюдения, заполнялись опросники CAT и mMRC, проводилась спирометрия. Результаты и их обсуждение. Распределение всех 76 больных позволило отнести к группе A $15,8 \%$ больных, к группе B - 38,15\%, к группе C - 2,5\%, к группе D - 40,8\%. Структура больных по классификации GOLD 2014 отличалась у пульмонолога и врача общей практики. После начала терапии гликопирронием через 8 нед объем форсированного выдоха за 1 с повысился на 6 $(5,0-9,0) \%$, значение $\Delta$ CAT-test улучшилось на 5,5 $(2,0-7,0)$ балла $(p<0,01)$. В результате число больных в группе А стало больше и составило $36,4 \%$ по сравнению с 9,1\% до лечения за счет перехода пациентов из группы В. Группа D уменьшилась в 2 раза за счет перехода пациентов с ХОБЛ в группы В и С. Заключение. Анализ показал возможность ведения пациентов с хронической обструктивной болезнью легких с учетом новых международных инициатив в реальной врачебной практике.

Ключевые слова: хроническая обструктивная болезнь легких, рекомендации, бронхолитики.

Для ссылки: Как выполняются положения GOLD 2014 в реальной врачебной практике? / В.И. Купаев, Л.А. Щелкунова, Н.А. Наговская, К.В. Гусаров // Вестник современной клинической медицины. — 2016. — Т. 9, вып. 3. C.18-22. 